\title{
The Improvement of Tourist-Village Promotion Through the Optimalization of Information and Communication Technology for Rural-Youth
}

\author{
Yogaprasta Adi Nugraha ${ }^{1}$, Dini Valdiani ${ }^{1}$, Eneng Tita Tosida ${ }^{1}$ \\ University of Pakuan, Pakuan Street No 1, Bogor, Indonesia
}

Corresponding authore-mail address: yogaprasta_adinugraha@unpak.ac.id

\begin{abstract}
Bogor Regency is one of the Jakarta's buffer cities that able to provide alternative tourism locations for the citizen of the capital and surrounding areas. Ciasmara Village is one of the tourism villages located in Bogor Regency. The main problem encountered by tourism in Ciasmara Village is the lack of promotion and limited infrastructure. These two problems are the biggest factors that hinder the tourism potential of Ciasmara village from being optimally managed. The purpose of this community service activity is to optimize tourism potential through the information and communication technology. Furthermore, the other purpose is to support the behavior shifting of the youth organization in terms of utilizing information and communication technology for the benefit of Ciasmara Tourism village promotion. The method used in this community service activity was discussion and direct training to Ciasmara Village's youth organization. The objective of this community service is Ciasmara Village's youth organization. In the beginning, the target amount of the training participants was at least 20 young people, because there were only 20 active members of the youth organization. In its implementation, this activity was attended by 31-35 participants, indicating that this community service was enticing for Ciasmara village's youths. Through interviews with the head of the youth organizations and the participants, they acknowledged that they were interested in participating in this activity because they felt they had a responsibility to develop village promotions, some of the youth said that they had social media and could promote their area for free. From interviews with several participants and village officials, it was found that this community service activity was able to motivate them to study photography more seriously and utilize social media for the promotion of rural tourism. This can be recognized from the development of official Instagram social media account owned by Ciasmara Village which is indeed focused on promoting tourism and governance in Ciasmara village.
\end{abstract}

Keywords: Information,communication technology, Tourism, and promotion 


\section{Introduction}

Bogor Regency is one of the satellite cities of the nation's capital psychologically afford to provide alternative tourism locations for the citizen of the capital and surrounding areas. Ciasmara Village of Bogor Regency is one of the tourism villages located in Bogor Regency. The main problem encountered by tourism in Ciasmara Village is the lack of promotion and limited infrastructure. These two problems are the biggest factors that hinder the tourism potential of Ciasmara village from being optimally managed. Tourism is a sector with high risk of failure due to its dependency on promotion and infrastructure support. This condition is a challenge for stakeholders, including rice farmers in Ciasmara Village, District of Pamijahan, Bogor Regency (Ardiansyah et al., 2020).

The characteristics of tourism in Ciasmara Village are quite distinctive from most tourism areas in Bogor Regency. Located at the foot of Mount Salak, the area is in the form of terraces instead of a vast expanse. Therefore, the treatment is different. Besides, the contour of the area which is in the foothill makes the community's residence location is detached from the tourism center. One example that is often encountered by tour maintainers in Ciasmara Village is substandard tourism promotion with limited scope; not optimally managed. The community only use the word of mouth promotion and limited social media. Another problem faced by tourism in Ciasmara village is the limited promotional infrastructure. Unavailability of an easily accessible large car park location makes this location difficult to reach by tourism cars and buses (Tosida et al., 2019).

The progress of information and communication technology can be viewed from both sides. Not only about the negative impacts that arise, but also there are positive impacts that are given to users. Information and communication technology today has begun to enter rural areas, as seen from the start of many young people who use social media and WhatsApp application. The use of information and communication technology is expected to overcome obstacles related to space and distance. Through information and communication technology, obstacles such as knowledge sharing between fellow citizens and policy holders can be overcome, besides that through information and communication technology, it is also expected to increase the capacity of Ciasmara villagers to manage tourism in the village (Tosida et al., 2019; 2020).

In the management of tourism villages, certainly the community has a stake in participating in its development. One alternative tourism development approach is the tourism village for sustainable rural development in the field of tourism. The active role of the community in the development of this tourism village needs to be followed by increasing the capacity of the village community so that the development of tourism potential can be more directed. Ciasmara Village has now been developed into a natural tourism village, considering that Ciasmara Village has the potential of waterfalls, hot springs, and rice fields in the form of abundant terraces. One effort that can be done to increase the interest of local foreign tourists to come to the Ciasmara Village is through an increase in promotional strategies through social media so that the tourism potential of the Ciasmara village can be recognized to a wide audience.

To create a quality tourist location in addition to funding and infrastructure support needed from the government, according to Cooper et.al in Sunaryo (2013) explains that in developing a tourist destination there are several components that must be considered, such as tourist attraction objects, accessibility, amenities, public facilities and institutions that have the authority, responsibility, and role in supporting the implementation of tourism activities. Based on the results of the current observations in the Ciasmara tourism village there are still no special institutions that oversee the operational activities of tourist attractions and are still managed by the surrounding community, so this is where the role of youth as a productive generation will be required in developing the Ciasmara Tourism Village.

\section{Basic Concepts of Information and Communication Technology}

Rogers (2003) stated the information society is "A nation whose majority of the workforce is already an information worker". The information workers include journalists, editors, editors, computer programmers, desktop publishing specialists, television producers, secretaries, public relations officers, 
advertising account executives, accountants, and clerks. What is the concept of information and what strength does it have? Understanding of the concept of information is very important so that we can be wise and prudent about information. To understand information, Fisher (1986) on Rogers (2003) presented three concepts of information as follows:

1. Information shows the facts or data obtained during the communication process information is conceptualized as a physical quantity that can be moved from one point to another, one individual to another individual, or one medium to another. The more a person obtains facts or data, the more that person will have information quantitatively.

2. The information shows the meaning of data. Information is the definition, purpose, or meaning contained in the data. A person's role is very dominant in giving meaning to data. Data will have information value if it is meaningful to someone who interprets it. A person's ability to give meaning to data will determine ownership of information. Interpretation of data or stimulus received by the brain will determine the quality of information. As a product of a "factory" (our brain), the quality of information is largely determined by the various elements used to process every stimulus that enters a person through the five senses, then passes on to the brain for processing based on a person's knowledge (frame of reference), experience (field of experience), taste (frame of interest), and faith (spiritual). The broader the knowledge, experience, and the better the taste and morality, the more quality information will be yielded. The process in our brain is known as an intellectual process (intellectual process).

3. Information as the amount of uncertainty measured by reducing the number of alternatives. Information is closely related to uncertainty situations. An increasingly uncertain situation will lead to much alternative information, which can be used to reduce such uncertainty.

To understand the process of data processing into information and messages, Henry Fayol and Frederick Taylor were quoted by Koontz, O'Donnel, and Wehrich (1986) on Rogers (2003) using an input-output model approach. According to Fayol and Taylor, input from the "factory" of information in the form of stimulus that is captured by the senses, then forwarded to the brain/nerve center. In the brain, the stimulus undergoes a process of transformation, which is processed with one's knowledge, experience, tastes, and faith. The output of the process is in the form of information that is remembered (memory) in a person or passed on to others. Information that is communicated to other people or audiences is called a message.

Information and messages are subjective. Why? Because information and messages are never valuefree. As an illustration, during the Second Gulf War (2003), Aljazeera Television tended to convey the news of the Iraq War from their point of view. It was said that the allied forces (the United States and Britain) were 'invaders' to Iraq because Iraq was a sovereign country. While CNN had a different point of view in broadcasting the same war. CNN broadcasted that allied forces were 'liberating gods' for the Iraqi people who were oppressed by Sadam Hussein's regime. It is obvious that the message conveyed has a different purpose. Hoveland States that (1953) that messages delivered to individuals or audiences have the aim to change the attitudes, opinions, and behavior of individuals or audiences. Through systematic disclosure of the formation of information and messages, the power of information and messages in changing the attitudes and behavior of others can be revealed.

The position of youth is complex and varied from childhood to adulthood; therefore it is pivotal to dismantle the concept systematically from many perspectives. United Nation defines youth as a person aged between 15 - 24 years old; this definition was made for International Youth Day. United Nation also defines childhood as a person aged less than 14 years old. Meanwhile, in Indonesia's Youth Law No 40/2009, defines youth as Indonesian citizen who are aged between 16 to 30 years old. Youth is a various matters that related to potential, responsibilities, rights, character, capacity, self-actualization, and the ideals of youth. There are various definitions of youth, whether in physical, psychological, biological, and sociological terms. Princeton defines youth as the time of life between childhood and maturity; early maturity; the state of being young or immature or inexperienced; the freshness and vitality characteristic of a young person, while in term of age, World Health Organization (WHO) defines "young people" as a person aged $20-24$ years and adolescent aged $10-19$ years. While in other countries, like Canada, after 
age 24, youth are no longer entitled for adolescent social services. But, most of countries defines youth as a person aged 18 years old, however the youth definition is diverse and cannot be separated with social, cultural, political and economical situation of a country.

Huijsmans (2010) states that the importance of putting childhood and youth as social construct, it means that the limitation of youth is varies through space and time, not merely related to biological characteristics. Cobb (2010) states that youth can be defined through several terminologies, such as biological, psychological, and sociological terminology. Biologically, youth is defined as a period of puberty that shapes a child's body to become more mature both sexually and physically. Hurlock (1980) states that youth developmental stages are not merely related to person heights nor ability, but more related to integration process of more complex structure. Moreover, Havigurst on Manning (2002) explains that there is a critical period where youth has a fast learning proses from their daily-life experiences. This notion has given the importance position of youth's surrounding systems in construction the idea of livelihood. Cobb (2010) also explains that the relation in family will be changing when entering adolescents. There is a tendency that adolescents and youth, as their age are increasing, they are decreasing their time with their family and do most activities outside their house. Huijsmans (2010) tried to address youth in active perspectives, youth as an agent of change. The study was revealing how young people in Lao actively become social actors and negotiate the process of becoming and not becoming a migrant. Torres - Harding et al. (2018) also tried to put youth as an active agent of change, the research found that young people who are seen disempowered due to their age and their dependence to adults, might seek positively impact social or community problems. Brofebrenner (1999) tries to see youth as part of their surrounding system, the notion about rural-youth is socially constructed it's explained by Brofenbrenner's Ecological System Model (1999). This model defines four kind of systems (environment) which in each system there are rules, norms, roles that can form youth identity, moreover this model is also trying to see individual environment in its correlation with relationship quality and context within.

\section{Methods}

In order to provide solutions to the problems that have been identified and mentioned above as well as ensuring that the assistance can run smoothly, this extension activity will use several approaches or methods, such as:

1. Lecture combined with discussion. This method was chosen to convey concepts that are important to be understood and mastered by youth. The use of this method was considered because the lecture method combined with images, animations, and displays can provide material that is relatively more communicative, concise, and easy. The material provided includes the development of information and communication technology and the importance of optimizing the use of information and communication technology in agriculture and rural areas, the utilization of WhatsApp and the internet on cell phones in the context of tourism information inquiry.

2. Training. This method was used to give the task to farmers to practice the use of communication and information technology in the context of tourism information inquiry and tourism promotion.

This community service activity had been carried out in three meetings, with a duration of 90 minutes per meeting. The first meeting explained the development of information and communication technology and the importance of optimizing the use of information and communication technology in tourism and rural areas. The second meeting incorporated a session on how to use WhatsApp and social media on mobile phones in the context of inquiring tourism information and using social media in developing tourism. In addition, there was also an introduction to the main tourism sites that can benefit the process of tourism development in the village of Ciasmara. The third meeting or the last meeting was the practice of how the youth are able to use WhatsApp as a means of discussion and the internet to find information about tourism and social media development. The training scheme will be explained in the following Table 1: 
Table 1. Community Service Activity Scheme in Ciasmara Village

\begin{tabular}{|l|l|l|}
\hline Meeting 1 & \multicolumn{1}{|c|}{ Material } & \multicolumn{1}{|c|}{ Equipment } \\
\hline Meeting 2 & $\begin{array}{l}\text { The development of information and } \\
\text { communication technology and the } \\
\text { importance of optimizing the use of } \\
\text { information and communication technology in } \\
\text { tourism and rural areas }\end{array}$ & $\begin{array}{l}\text { Projector, laptop, room, board } \\
\text { marker, whiteboard, and Wi- } \\
\text { Fi }\end{array}$ \\
\hline Meeting 3 & $\begin{array}{l}\text { Utilization of WhatsApp and the internet on } \\
\text { cell phones in the context of inquiring tourism } \\
\text { information and the use of social media }\end{array}$ & $\begin{array}{l}\text { Cell phones, projector, Wi-Fi } \\
\text { and laptop }\end{array}$ \\
\hline & $\begin{array}{l}\text { Practicing on how youth are able to utilize } \\
\text { WhatsApp and social media for tourism } \\
\text { development in the village of Ciasmara }\end{array}$ & Wi-Fi, cell phones \\
\hline
\end{tabular}

Participants in this activity are youth in Ciasmara Village, District of Pamijahan, especially members of youth organizations who are still active in regular monthly meetings. Basically, this community service activity will not have a direct impact, because the process of finding and exchanging information through information and communication technology must go through routine and often practiced activities. This activity needs to be trained regularly and continuously, and should ideally be carried out periodically. Therefore, evaluation or control is needed once this community service is done.

\section{Results and Discussion}

\subsection{Context of Youth in Ciasmara Village}

In this activity, it was found that the progress of information and communication technology in the village can be viewed from two sides. Not only about the negative impacts that arise, but there are also positive impacts on users. Youth in the village use social media to promote rural tourism, but on the other hand, there is logical consequence such as internalization of new values, which tends not always to be in line with existing village norms. Information and communication technology today has begun to enter the remote villages, this can be seen from the many young people in the village who use social media and WhatsApp, Facebook, and Instagram applications. The proper use of information and communication technology is expected to be able to overcome obstacles related to space and distance such as knowledge sharing between fellow youth and stakeholders or even a broader community.

Social media is not somewhat a new thing for youth in Ciasmara village, some previous studies have explained the use of social media in Ciasmara village. According to Winangun and Nugraha (2018), the Internet and social media are very closely related matters, based on the 2017 APJII social media it is known that 87.13 percent of respondents accessed social media. This was not much different from the data obtained by the youth of Ciasmara village who accessed or used social media at 83 percent. Judging from the number of accounts, it was found that most participants have one social media account with a percentage of 47.1 percent, while 38.2 percent have two social media accounts, and the remaining 14.7 percent have three social media accounts. Based on the type of social media owned by youth in Ciasmara Village, it was found that all the young people have accounts on the Facebook platform, while $32.4 \%$ of them use the WhatsApp platform, and Instagram was the least at 23.5\%. Facebook is a social media used by all young people in Ciasmara village because Facebook has a feature as a medium for exchanging messages (chatting).

\subsection{Description of Community Service Activity}

The Community Service Activity of Optimizing the Use of Information and Communication Technology which was carried out with face-to-face events and practicing the use of information and communication technology was running properly with several obstacles encountered. Community service activities are divided into three meetings: 
The first meeting was held on Thursday, March 14, 2019 in the Ciasmara Village Office Hall. It took place from 9:00 to 12:00. This meeting discussed: basic photography techniques using a mobile phone camera. Participants at this meeting numbered about 31 people consisting of young people who are members of the Ciasmara village youth organization. The meeting began with an opening by the village head and the village secretary, followed by an initial discussion on how young people use their cell phones. At this meeting, the first speaker tried to explain the challenges and weaknesses of using mobile phones for taking photos.

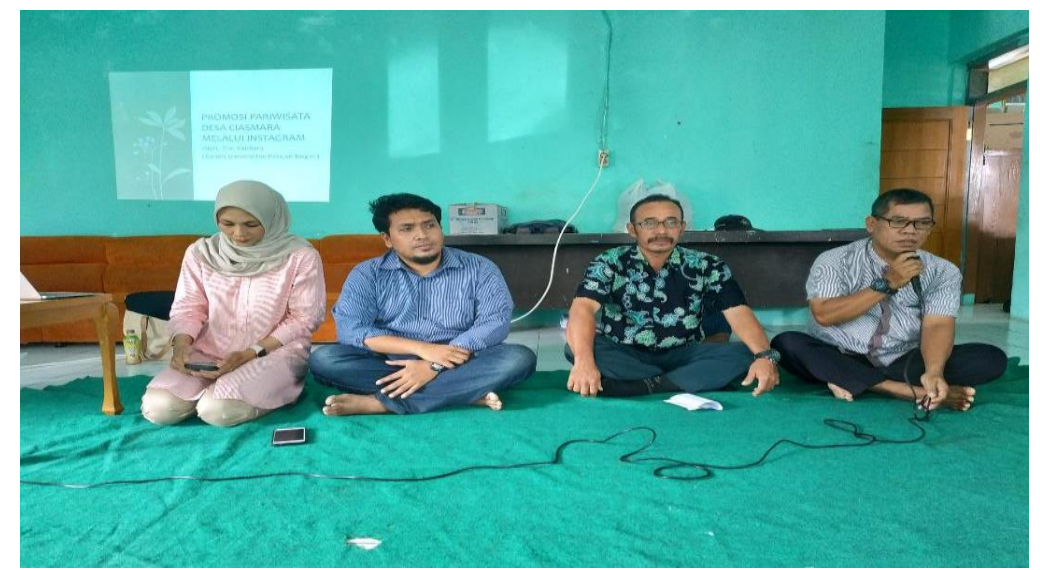

Figure 1: Training of mobile photography using mobile phone

The second meeting was held on Thursday, March 21, 2019, in the Ciasmara Village Office Hall, which started from 09.00 till 13.00. This meeting discussed: Utilization of Social Media for the Promotion of Tourism in Ciasmara Village. Participants at this meeting numbered about 35 young men and women who were members of the youth organization in Ciasmara Village. This meeting began by asking about the results of the first meeting, some members of the youth group, in general, could mention the advantages of using information and communication technology for photography and social media. At the second meeting, the speakers focused on the introduction of the Instagram application for the promotion of Ciasmara Village tourism. Most participants admitted that they already have an Instagram application on their mobile phones, but young people have not been able to optimize the use of Instagram in promoting their village tourism. Only a few young people were already familiar with the use of Instagram in promoting tourism.

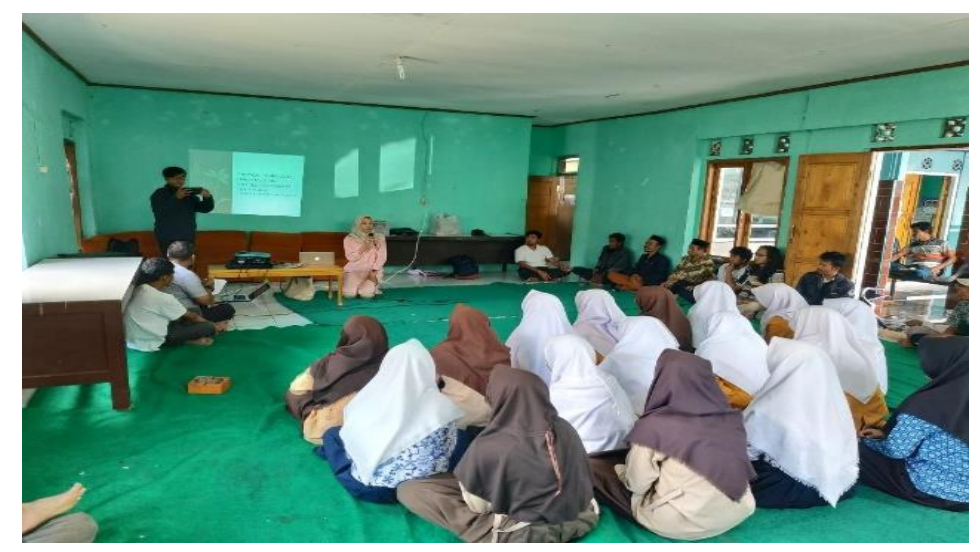

Figure 2: Training of using Instagram as medium for promotion 
The third meeting was held at the same time as the second meeting. After the informant explained about the use of information on photography and social media, participants who had an internet mobile phone were asked to look for tourism information via the internet. Not all participants had an internet mobile phone to access the internet, so in this training process, only farmers who had an internet connection that can participate. These farmers are expected to be able to train their fellow farmers who did not have mobile phone with internet access. In the next week on March 28, 2019, around 10:00 WIB, this community service activity was followed by discussions with the village secretary, the head of the Bumdes (village-owned enterprise), and the head of the youth organization. Information was obtained from the discussion, the development of tourism potential in the Ciasmara Village began to be launched as a Tourism Village in Bogor Regency since 2007 and now it has been reactivated to integrate all existing objects with the youth organization and the Bumdes of Ciasmara village.

\subsection{Effectiveness of Community Service Activity}

As previously outlined, the target amount of the trainees was at least 20 members of the youth organization. Somehow in its implementation, this activity was attended by 30 participants. Thus, it can be said that the target audience exceeds the target. This figure shows that this community service activity was interesting to young people in the village of Ciasmara. Through the results of interviews with the head of youth organization and several participants from this community service, they admitted that they were interested in participating in this activity because the biggest problem of tourism in the village of Ciasmara was the lack of effective and efficient promotion. However, they also acknowledged that the use of information and communication technology to farmers in Ciasmara Village was difficult because there were several major obstacles, including: (1) The internet network in the village is unstable and it tends to be difficult to upload videos, (2) Not all young people in the village of Ciasmara have a sense of obligation to promote their village and relying it entirely on the village officials.

The main objective of this community service activity is to shift the behavior of village youth in terms of utilizing information and communication technology for the promotion of rural tourism. From interviews with several participants and village officials, it was found that the community service activity had helped to improve the skills of youth, especially in terms of basic competencies in developing photography skills and the use of social media, even though this change in behavior was not evenly adapted, only effective to some participants. This is due to several things, among others: (1) The duration of community service activity was relatively too short (60 to 90 minutes), while the initial assumption was that all youth were already familiar with using information and communication technology. (2) There has not yet been a vision about the direction of village tourism in the future, therefore the promotion is still sporadic.

Most of the material targets for community service activity have been conveyed such as (1) Development of information and communication technology and the importance of optimizing the use of information and communication technology in agriculture and rural areas, and (2) Utilization of cellphone cameras and social media on in the context of developing tourism potential. There was one material that was not delivered optimally, which was the practice of making and editing videos using a mobile phone, that is because most youths did not have mobile phones with sufficient specifications, only a few did. This is the main obstacle faced by resource persons in practicing the use of information and communication technology to youth. Somehow the training process of using information and communication technology continued to be carried out, but only focused on some participants who already have basic competencies in information and communication technology. Judging from the mastery of the material, the participants' ability was still inadequate due to several things, such as: (1) restricted duration in the delivery of the material, (2) the diverse participants' ability in the context of the use of information and communication technology, and (3) insufficient signal of network and mobile phone specifications to optimize the creation of promotional videos.

Ciasmara village currently has an Instagram account that contains all the activities of the village apparatus and village tourism promotion activities, besides that the Instagram account manager already understands how to use the hashtag (\#) to make it easier for people to search for Ciasmara village. 


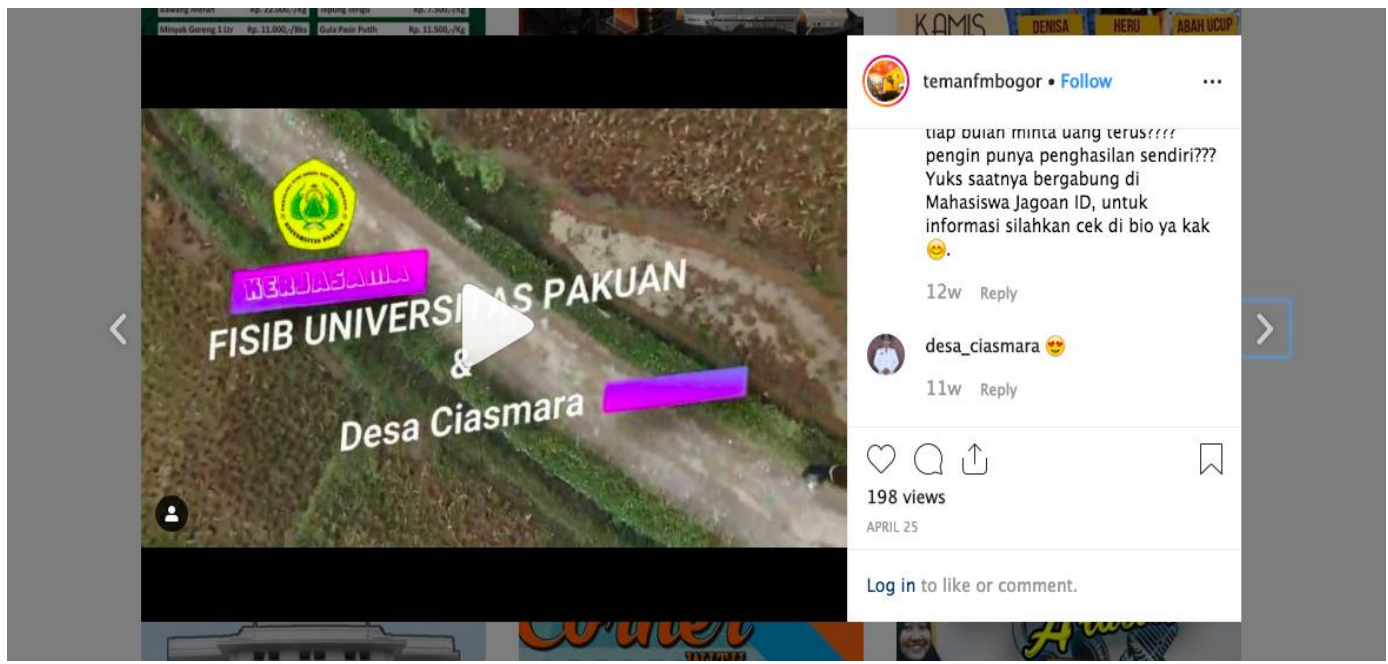

Figure 3: The promotional video for tourism villages in Instagram and distributed more widely by the Bogor Regency Government

\section{Conclussion}

The community service activity had helped to improve the skills of youth, especially in terms of basic competencies in developing photography skills and the use of social media, even though this change in behavior was not evenly adapted, only effective to some participants. This is due to several things, among others: (1) The duration of community service activity was relatively too short (60 to 90 minutes), while the initial assumption was that all youth were already familiar with using information and communication technology. (2) There has not yet been a vision about the direction of village tourism in the future, therefore the promotion is still sporadic. Most of the material targets for community service activity have been conveyed such as (1) Development of information and communication technology and the importance of optimizing the use of information and communication technology in agriculture and rural areas, and (2) Utilization of cellphone cameras and social media on in the context of developing tourism potential. There was one material that was not delivered optimally, which was the practice of making and editing videos using a mobile phone, that is because most youths did not have mobile phones with sufficient specifications, only a few did..

\section{References}

Apjii. (2016). Infografis Penetrasi \& Perilaku Pengguna Internet Indonesia Survey. Tekno Preneur.

Ardiansyah, D., Tosida, E.T., Waluyo, A.D. (2020). Optimization of Accounting Information System Reiinforcing of Tourism Based Small and Medium Enterprises (SMEs) : International Journal of Scientific \& Technology Research, Vol 9 Issue 03, March 2020, pp 1282-1286.

Crawford, M. (2011) The Case for Working with Your Hands: Or Why Office Work is Bad for Us and Fixing Things is Good. London: Penguin Books.

Chessa, A. G., and Murre, J. M. (2004). A memory model for internet hits after media exposure. Physica A: Statistical Mechanics and its Applications, Vol. 333, pp. 541-552.

Cobb, NJ. (2010). Adolescence: Continuity, Change, and Diversity, Seventh Edition, Sinauer Associates. USA. 
Huijsmans, RBC. (2010). Migrating Children, Household, and Post - Socialist State: An Ethnographic Study of Migration and Non- Migration by Children and Youth in an Ethnic Lao Village. PhD Theses. Durham University.

Jayawinangun, R, and Nugraha, Y.A. (2018). Utilization of Internet and Social Media among Rural Youth. Jurnal Wahana, Vol. 24, No 2.

Kasten, K. (2013). Media Exposure and Risk. Wyman Street, Waltham, MA: Elsevier.

Katz, C. (2004). Growing Up Global: Economic Restructuring and Children's Everyday Lives. Minneapolis: University of Minnesota Press.

Manning, M. L. (2002). Havighurst's Developmental Tasks, Young Adolescents, and Diversity. The Clearing House: A Journal of Educational Strategies, Issues and Ideas, Vol. 76, No. 2, pp. 75-78

Nugraha, YA. (2012). Correlation Between Parents, Peers, and Mass Media with Rural Youth Attitude towards Agricultural Work. Tesis. Institut Pertanian Bogor. Bogor.

Nugraha, Y.A. dan Herawati, R. (2015). Unmasking the Reality of Youth in Agriculture. Jurnal Analisis Sosial, Vol. 19, No. 1.

Rheingold, H. (1993). The Virtual Community: Homesteading on the Electronic Frontier.Reading. Addison-Wesley.

Rogers, E. M. (2003). Diffusion of innovations. New York: Free Press.

Ronfenbrenner, U. (1999). Environments in developmental perspective: Theoretical and operational models. In S. L. Friedman \& T. D. Wachs (Eds.). Measuring environment across the life span: Emerging methods and concepts (p. 3-28). American Psychological Association. https://doi.org/10.1037/10317-001.

Torres-Harding S, Barber A, Hilvers J, Hobbs N, and Maly M. (2018). Children as Agent of Social and Community Change: Enhancing Youth Empowerment through Participation in a School-based social-activism project. Journal of Education, Citizenship, and Social Justice, Vol. 13 No. 1, pp. $3-18$.

Tosida, E.T., Ardiansyah, D., Walujo, A.D., Sofyandi, A. (2019). System Design of Augmented Reality Technology to Strengthen Sustainable Imaging of Kujang Products Based on Local Culture. International Journal of Recent Technology and Engineering (IJRTE), ISSN : 2277-3878, Vol. 8, Issue 4, Nov 2019, pp 5940- 5949. DOI : 10.35940/ijrte.D9016.118419.

Tosida, E.T., Wahyudin, I., Andria, F., Djatna, T., Ningsih, W.K., Lestari, D.D. (2020). Business Intelligence of Indonesian Telematics Human Resource : Optimizing of Customer and Internal Balanced Scorecards. Journal of Southwest Jiaotong University, Vol. 55 No. 2, Apr (2020). DOI : 10.35741/issn.0258-2724.55.2.7.

White, B. (2012) Agriculture and the Generation Problem: Rural Youth, Employment and the Future of Farming. IDS Bulletin, Vol. 43, No. 6, pp. 9-19.

White, B. (2019). Rural Youth, Today and Tomorrow. Rural Development Reports. IFAD 